\title{
The influence of subthreshold membrane potential oscillations and GABAergic input on firing activity in striatal fast-spiking neurons Andreas Klaus*1,3, Johannes Hjorth ${ }^{2,3}$ and Jeanette Hellgren-Kotaleski ${ }^{1,2,3}$
}

\author{
Address: ${ }^{1}$ Department of Neuroscience, Karolinska Institute, 17177 Stockholm, Sweden, ${ }^{2}$ School of Computer Science and Communication, Royal \\ Institute of Technology, AlbaNova University Centre, 10691 Stockholm, Sweden and ${ }^{3}$ Stockholm Brain Institute, 17177 Stockholm, Sweden \\ Email: Andreas Klaus* - Andreas.Klaus@ki.se \\ * Corresponding author
}

from Eighteenth Annual Computational Neuroscience Meeting: CNS*2009

Berlin, Germany. 18-23 July 2009

Published: 13 July 2009

BMC Neuroscience 2009, I0(SuppI I):P244 doi:I0.II86/I47I-2202-I0-SI-P244

This abstract is available from: http://www.biomedcentral.com/I47I-2202/I0/SI/P244

(c) 2009 Klaus et al; licensee BioMed Central Ltd.

\section{Poster presentation}

The striatum is the main input stage of the basal ganglia system, which is involved in executive functions of the forebrain, such as the planning and the selection of motor behavior. Feedforward inhibition of medium-sized spiny projection neurons in the striatum by fast-spiking interneurons is supposed to be an important determinant of controlling striatal output to later stages of the basal ganglia [1]. Striatal fast-spiking interneurons, which constitute approximately $1-2 \%$ of all striatal neurons, show many similarities to cortical fast-spiking cells. In response to somatic current injection, for example, some of these neurons exhibit spike bursts with a variable number of action potentials (so called stuttering) [2-4]. Interestingly, the membrane potential between such stuttering episodes oscillates in the range of $20-100 \mathrm{~Hz}[3,5]$. The first spike of each stuttering episode invariably occurs at a peak of the underlying subthreshold oscillation. In both cortex and striatum, fast-spiking cells are inter-connected by gap junctions $[6,7]$. In vitro measurements as well as theoretical studies indicate that electrical coupling via gap junctions might be able to promote synchronous activity among these neurons $[6,8]$. Here we investigate the possible role of subthreshold oscillations on the synchronization of sub- and suprathreshold activity in a model of electrically coupled fast-spiking neurons. We use the model of Golomb et al. [3], which we extended with a dendritic tree so as to be able to simulate distal synaptic input. We show that gap junctions are able to synchronize subthreshold membrane potential fluctuations in response to somatic current injection. However, the oscillations are only prevalent in the subthreshold range and therefore require enough membrane potential depolarization [5]. In response to synaptic input, our model neuron only enters the subthreshold oscillatory regime with AMPA and NMDA synapses located at distal dendrites. Proximal synaptic input leads to more random fluctuations of the membrane potential, reflecting a smaller extent of dendritic filtering of the Poisson-distributed postsynaptic potentials. We furthermore investigate the effect of GABAergic (i.e. inhibitory) input to the model of the fast-spiking neuron and predict that inhibitory input is able to induce a stuttering episode in these cells. We finally discuss our results in the context of the feedforward inhibitory network, which is likely to play an important role in striatal and basal ganglia function.

\section{Acknowledgements}

AK, JH and JHK acknowledge support from the Swedish Research Council and the Parkinson's Foundation. AK is in addition supported by the NIHKarolinska Institute joint PhD program.

\section{References}

I. Tepper JM, Koós T, Wilson C): GABAergic microcircuits in the neostriatum. Trends in Neurosci 2004, 27:662-669.

2. Taverna S, Canciani B, Pennartz CM: Membrane properties and synaptic connectivity of fast-spiking interneurons in rat ventral striatum. Brain Res 2007, I 152:49-56.

3. Golomb D, Donner K, Shacham L, Shlosberg D, Amitai Y, Hansel D: Mechanisms of firing patterns in fast-spiking cortical interneurons. PLoS Comput Biol 2007, 3:e I56.

4. Druckmann S, Banitt Y, Gidon A, Schürmann F, Markram H, Segev I: A novel multiple objective optimization framework for con- 
straining conductance-based neuron models by experimental data. Front Neurosci 2007, I:7-18.

5. Bracci E, Centonze D, Bernardi G, Calabresi P: Voltage-dependent membrane potential oscillations of rat striatal fast-spiking interneurons. J Physiol 2003, 549:121-1 30.

6. Galarreta M, Hestrin S: Electrical synapses between GABAreleasing interneurons. Nat Rev Neurosci 200I, 2:425-433.

7. Fukuda T: Network architecture of gap junction-coupled neuronal linkage in the striatum. J Neurosci 2009, 29: I235- 1243.

8. Mancilla JG, Lewis TJ, Pinto DJ, Rinzel J, Connors BW: Synchronization of electrically coupled pairs of inhibitory interneurons in neocortex. J Neurosci 2007, 2:2058-2073.

Publish with Bio Med Central and every scientist can read your work free of charge

"BioMed Central will be the most significant development for disseminating the results of biomedical research in our lifetime."

Sir Paul Nurse, Cancer Research UK

Your research papers will be:

- available free of charge to the entire biomedical community

- peer reviewed and published immediately upon acceptance

- cited in PubMed and archived on PubMed Central

- yours - you keep the copyright

Submit your manuscript here:

http://www.biomedcentral.com/info/publishing_adv.asp 